Christianity and Social Scientific Perspectives on Sport: introduction to the special issue

Tom Gibbons \& Stuart Braye

t.gibbons@tees.ac.uk

Department of Psychology, Sport \& Exercise, Teesside University, Middlesbrough, UK

\begin{abstract}
The aim of this introduction is to provide a context for the contributions that follow in this special issue. The origins and scope of, as well as the rationale for, this special issue are discussed before a summary of, and brief commentary on, the eight papers is provided. Suggestions for comparisons between some of the papers is provided to help readers to consider the breadth and potential for further research.
\end{abstract}

\title{
Origins and scope
}

There has been a dramatic increase in academic research activity and practical initiatives on the topic of sports and Christianity, and its cultural significance during the past decade. Academics have correctly highlighted the fact that Christian theologians have been slow to recognize this significance (Hoffman 2010; Twietmeyer 2008; 2009; Watson 2011). Thus, the Faculty of Health and Life Sciences at York St John University, York, UK, hosted the Inaugural Global Congress on Sports and Christianity (IGCSC), 24-28th August 2016 in collaboration with the Bible Society. For the area of sports studies/the social scientific study of sport, there was a thematic strand at the congress titled 'Christian Sociological Perspectives on Sport' from which this special edition of Sport in Society has partially emanated. 
Following the event, a call for papers was publicized widening the scope of interest to 'Christian social scientific perspectives on sport', rather than being solely sociological in nature. This call for papers resulted in a wealth of potential contributions from a range of disciplinary areas, including: religious studies, psychology, sociology, anthropology, philosophy and theology. The papers that were selected for inclusion in the special issue are purposely eclectic in order to demonstrate the diversity of current research occurring in the area of Christianity and social scientific perspectives on sport which attempts to bridge divisions between various social science disciplines and theology or religious studies, through varied, novel and interesting explorations of sport in its various forms.

\section{Rationale}

Whilst some studies on the relationships between sport and various 'faiths' or 'religions' exist, sports and Christianity is the fastest growing area of research within this field. However, this area of scholarship at present lacks examples of theoretical-empirical studies (see for example the diversity of scholars mentioned in Watson and Parker's 2013 and 2014 comprehensive systematic reviews of literature on sport and Christianity). Whilst there are some scholars attempting to inject a more social scientific standpoint into research on Christianity and sport (cf. Gibbons 2017; Gibbons and Braye 2017; Howe and Parker, 2012; 2014; Parker and Watson, 2014), at present there appears to be little to no reflection on the relationship between Christianity and social scientific perspectives within this literature or indeed within sports studies/the social scientific study of sport. This can be observed for example in John Horne's (2015) recent entry on the topic of 'sport' in Oxford Bibliographies in Sociology in which studies on religion and sport are almost entirely absent, bar some reference to studies on football and sectarianism. 
In a recent essay published in the Sociology of Sport Journal (one of the leading journals in sports studies/the social scientific study of sport), social scientists Shilling and Mellor $(2014,350)$ recognised that the topic of 'religion' has previously been 'marginalized' in the social scientific analysis of sport over the last two decades. They noted that 'studies focused purely on the secular dimensions of sport can be unhelpfully narrow' and encouraged sports sociologists to explore religious and sacred aspects of sport (Shilling and Mellor 2014, 352). The purpose of this special edition of Sport in Society is to provide a forum for authors to begin to address what appears to be a significant lacuna in the expanding research on the multidisciplinary topic area of sports and Christianity. The goal is to spark debate between Christian and non-Christian scholars and hopefully begin the snowball of further studies into the potential connections between Christian social scientific perspectives and the social scientific study of sport. This occurs through discussion of the past, present and future of Christian social scientific perspectives and their potential to inform sports studies/the social scientific analysis of sport.

\section{Summary of contributions to this special issue}

Given the eclectic nature of the focus of the papers that make up this special issue, some considerable time was spent discussing how best to overcome the problem of arranging them. However, we have attempted to organise the contributions by type and theme, as such, the special issue is divided into three sections.

The first section includes three papers which are purely theoretical in nature and focus on broad issues within the study of sport, including: an essay on the need for a Christian sociological approach to studying the social scientific aspects of sport (Tom Gibbons, Nick J. Watson and Mark Mierzwinski); an argument for regarding sport as 'Cultural liturgy' (Zachary Smith); and, the development of a Christian sociological approach to embodiment 
(Mike Tyler and Tom Gibbons). The fourth and fifth papers make up the second section. These are essays focused on more specific issues within the social scientific study of sport, including: the importance of athletic religious apparel in the Christian CrossFit community (Alexander Ornella); and, a theological critique of the claims made by the International Paralympic Committee regarding disability equality in the UK (Stuart Braye). The third and final section of the special issue is comprised of three further papers, which are all empirical studies. The sixth paper is a study exploring the views of Dutch Orthodox Reformed Christian youths regarding participation in sport and physical activity (Froukje Smits, Annelies Knoppers and Corina Van Doodewaard); the seventh paper is a study on how Canadian youths use religious and personal rituals to enhance their confidence in sport (Matt Hoven); and, the eighth paper is a study exploring Christian academicians views of the body, sport and religious experience. In what follows we provide a commentary on each paper within the three sections.

\section{Theoretical arguments within the Christian social scientific study of sport}

The opening paper by Gibbons, Watson and Mierzwinski 'Christianity as Public Religion: A Justification for using a Christian Sociological Approach for Studying the Social Scientific Aspects of Sport', makes a case for why Christianity should be regarded as 'public religion' and uses this as a basis for advocating the use of a Christian sociological approach for studying the social scientific aspects of sport. The authors argue that many of the issues inherent in modern sport which have been of interest to social scientists of sport, including for example, abuse; violence; political/national divisions; sectarianism; cheating; playing through pain and injury; overtraining; burnout; inequalities; financial greed and corruption; use of performance enhancing drugs/doping, etc., are all an indirect result of its increasing secularisation. The authors argue that secularisation has reduced the importance of playing 
sport for the inherent virtues that were instilled in modern sports by English public schools under the influence of muscular Christianity. Considering elite sport is one of the most publicly debated aspects of everyday life, the authors argue that it should not only be studied from a secular perspective and the concept of public religion is drawn upon to help justify the use of religious ideas in the study of public issues. Since Christianity was always intended to be used as a public force for the good of society (and there are numerous examples to support this in the New Testament), the authors encourage sociologists of sport to draw upon Biblical themes/theological ideas alongside secular sociological theories and concepts when studying sport.

In the second paper, 'Can sport be regarded as 'Cultural Liturgy'? Recognizing the significance of the liturgical frame for the social scientific study of sport', Smith critically analyses previous attempts to theorize sport and its ethos using the religious language of liturgy in order to determine the significance and appropriateness of such language for studying sport. Like the Gibbons et al. paper before it, in this paper Smith seeks to suggest a theoretical concept for use as a framework for future social scientific studies of sport. To this end, after careful consideration and critique of a variety of theological and non-theological contributions, Smith argues that James K.A. Smith's (2012) concept of cultural liturgy is most useful for not only recognising the significance of the liturgical frame for studying sport but, perhaps more importantly, he demonstrates how this concept has scope to be utilised by both theological and non-theological scholars of sport.

The third paper, by Tyler and Gibbons, 'Redeeming the Habitus: A Christian Sociological approach to Embodiment in Sport', focuses on the topic of the body in sport considering this has been a central concern for sports sociologists in the past. The body is also a central concern for Christians and Tyler and Gibbons argue that secular explanations of embodiment in sport are not adequate for fully explaining the role and significance of religion 
in society and thus also in sport. The authors seek to demonstrate how the sociological concept of 'habitus', commonly associated with the secular social scientific approach of Pierre Bourdieu, actually has a rich history of use by theologians in Christian conceptions of embodiment. Tyler and Gibbons seek to combine both theological and sociological insights in order to 'redeem' the concept of habitus as a more rounded tool that can be used in order to make sense of embodied persons in sport.

All three papers in this opening section make novel theoretical contributions that are designed to assist scholars in their social scientific analyses of sport.

\section{Specific issues within the Christian social scientific study of sport}

The fourth paper, by Braye, 'Tanni Grey-Thompson - 'The one that got away': A Theological Analysis of Feticide, Infanticide and the Deviant Paralympic Success Story', is focused on the very different social scientific issue of disability equality within sport. Braye seeks to provide a theological critique (drawing upon Christian bio-medical ethics and biblical references) of the Paralympic Games, its athletes and the media through a powerful and alarming discussion of the realities of feticide and infanticide of disabled children in the UK that occur in stark contrast to the claims made by the International Paralympic Committee regarding improvements in equality for disabled people. The world famous former Paralympian, Tanni Grey-Thompson, is used as an example to highlight the paradoxical relationship between feticide and infanticide figures regarding disabled children in the UK and success in Paralympic sport.

The fifth paper, by Ornella, “Jesus Saves' and 'Clothed in Christ': Athletic Religious Apparel in the Christian CrossFit Community', focuses on the social scientific issue of consumption practices in sport. Ornella looks at the relationship between sport, fashion and Christianity through a unique case study of the popular sport of CrossFit. According to 
Ornella, CrossFit is a sport that has grown rapidly over the last 15 years and has attracted a sizeable Christian community, particularly in the USA. The specific focus of the essay is on the meaning of religious athletic t-shirts that are marketed by Christian sports apparel companies and intended to be worn by Christian CrossFit athletes. Ornella argues that these tshirts go beyond just being mere professions of faith and have a far more in-depth theological meaning. The author makes a strong case to suggest that these Christian CrossFit t-shirts should be taken seriously as religious-sacramental practice, but also argues that they make faith consumable.

Both papers in this section offer unique, and at times, controversial, insights into distinct issues that currently exist within the social scientific study of sport that few previous authors have explored in the past.

\section{Empirical studies within the Christian social scientific study of sport}

The sixth study, "We must not engage in the blind glorification of sport': Christian Orthodox Youths negotiate dominant societal and alternative Reformed Sport Discourses', by Smits, Knoppers and Van Doodewaard, offers a rare investigation into the place of sport and physical activity in the lives of a particular Christian community - the Dutch Orthodox. The authors tell us that Orthodox Reformed Christians (ORC) number around 250,000 in the Netherlands and live together in closed communities in an area known as 'the Bible belt'. The authors use their unique access to this population and their understanding of post-structural sociological perspectives to discover how governmentality enables Dutch ORC youths to resist dominant societal discourses that promote participation in sport. The paper is based upon a study involving a combination of semi-structured interviews and focus groups with 32 ORC teenage youths in the ORC high schools where they are based. Findings reveal the power of governmentality, including a strict adherence to certain biblical passages, used to 
actively discourage sports involvement in these communities, but also how ambiguity can enable some examples of resistance to dominant norms to occur amongst these youths.

The seventh study by Hoven, 'Re-Characterizing Confidence because of Religious and Personal Rituals in Sport: Findings from a Qualitative Study of 15 year old StudentAthletes', is a psychological study highlighting the significance of faith to understanding confidence in sport. The study is based upon 12 interviews with 15 -year old student-athletes at two Canadian Catholic high schools. The study demonstrates how this sample of youths revealed the use of religious and personal rituals for building their confidence when competing in various sports. Examples of religious and personal rituals that youths reported using were spiritual self-reflection, superstitions, prayer, as well as other distinctly religious rituals. Hoven calls for sports psychologists to not dismiss the importance of such religious and personal rituals when attempting to understand player confidence. He also encourages further empirical studies that seek to explore the existential and spiritual dimensions underpinning the optimal performance of athletes.

The eighth and final paper in this collection is titled 'Single, Separate or Unified? Exploring Christian Academicians Views of the Body, Sport and Religious Experience', by Sullivan. Since sports scholars shape theory and practice as well as prepare and enlighten future sport practitioners on thinking about the human person in relation to sport, Sullivan considered it worthwhile to explore and understand how they actually conceptualize the body and religious experience within the embodied activity of sport. The study is based on eleven semi-structured interviews with faculty members teaching in sport-related units at Christian universities in the USA and Canada. Findings revealed that the participants' views of human personhood influenced their perception of embodiment and the type and quality of religious experience possible within sport. Sullivan argues that religious faith informs both the 
understanding, as well as the practice, of sport and urges that these findings have significance for both religious as well as non-religious sports practitioners.

The three papers that comprise this final section showcase mutli-disciplinary examples of empirical research that is being conducted within the social sciences on the relationship between sport and Christianity.

\section{Concluding remarks}

The collection of papers included in this special issue address a range of Christian social scientific perspectives already being used within the study of sport. The collection highlights not only the quality of this research, but also its broad scope and appeal to sports academics and practitioners alike. It also highlights some of the many areas of research that are still in much need of exploration from a Christian social scientific perspective. Although we deliberated over the categorizing of the studies resulting in the three themes outlined above, in what follows we have offered some suggestions for comparisons across these themes.

The CrossFit study by Ornella and the Dutch Orthodox Reformed Christians (ORC) study by Smits, Knoppers and Van Doodewaard, when considered together provide a paradox of expressions and lived experiences of the same Christian faith. In Ornella's analysis, the Biblically motivated slogans of 'Jesus saves' and 'Clothed in Christ' worn by CrossFitters would be arguably understood and supported by participants in the ORC study. However, the placing of them adorned across the tiny t-shirted and braless chests of women, like American CrossFitter Andrea Ager, is about as far removed from the ORC world as it is possible to be, thus highlighting the complexity of the relationship between Christianity and sport. Interpretations and applications of Biblical Scripture clearly vary between the Christian CrossFitters and the ORC community and sport is a context which brings this to the fore. 
Further, Smits, Knoppers and Van Doodewaard's study also compares interestingly with Hoven's study of Canadian teenagers as their collective young participants again present a dichotomy of lived expressions of the same faith. Hoven's Canadian teenage participants provide an interesting perspective as they navigate their way through sports participation with prayer and faith - though not all are Christian adherents. Smits, Knoppers and Van Doodewaard's Dutch teenage participants are also living with expressions of Christianity, though their practice is to navigate away from sport rather than engage in it, and citing Biblical reasons for doing so.

Two papers examining embodiment are, Tyler and Gibbons theorizing around the term habitus and its Christian history, and Sullivan's empirical study on the views of Christian academicians. Sullivan's participants' use of everyday unambiguous language about their views on the merging and/or dissecting of mind, body and spirit highlight holistic and dualistic concepts that personify some of the theorizing of Tyler and Gibbons. In addition, Braye's Paralympic study applies theology to pinpoint a very specific issue in relation to the devaluing of unborn and newborn disabled children's bodies. In light of Tyler and Gibbon's theorizing around embodiment, dualistic and holistic thought, the contrast of these two studies provides a challenge to what it means for us as human beings to be people with different bodies but all created in the image of God. This challenge is stretched further by also considering Ornella's CrossFit study where the necessarily perfect - and semi-naked - body is unashamedly worshipped, while in Braye's study the so called imperfect - and naked - body is unashamedly exterminated.

The aim of highlighting these comparisons is to assist our academic peers and students of sport to negotiate what may be a new field to some. It would be helpful to the expansion of this field for academics to find their own comparisons and contradictions between the studies herein and respond to those we may have missed. The topics covered in 
this special edition are broad in scope touching the diverse elements of, sports academics in Christian colleges in America and Canada, Christian Orthodox youth in the Netherlands, the sport of CrossFit, the psychology of Catholic high school youth in Canada, the Paralympic Games, the language of cultural liturgy in sport, sociological theory, philosophy and theology. These studies demonstrate the potential within the social scientific analysis of sport for other sites of research where theological consideration can add to meaning and insight.

We hope that the studies within this collection will be used by religious and nonreligious alike to ensure that the social scientific study of sport is challenged to overcome the dominance of secular viewpoints and to encourage further input from Christian perspectives and religious topics so that studies of religion and sport are no longer restricted to the 'discrete corner' to which they have previously been allocated within sports studies (Shilling and Mellor 2014, 350). These Christian perspectives ought not to be ignored by academics

simply for being Christian on the basis that one is non-religious or anti-religious. If we may use an overly simple scenario to illustrate our point: if a world record breaking athlete vehemently claimed that eating 33 chocolate bars each morning was the secret of her success, sports scientists and nutritionists would hotly debate the claim. However, if she claimed that her faith in Jesus Christ was the reason for her success - as some do (Gibbons and Braye 2017) - one might be tempted to ignore it as just another psychological approach or ritual practice. However, if our academic discipline of the social sciences in sport is to be taken seriously, then some of us are duty bound to engage with Christian perspectives.

\section{References}

Gibbons, Tom. 2017. "Challenging the Secular Bias in the Sociology of Sport: Scratching the Surface of Christian Approaches to Sociology." In Global Perspectives on Sports and Christianity, edited by A. Adogame, N.J. Watson \& A. Parker. London: Routledge. 
Gibbons, Tom and Stuart Braye. 2017. "“I pray that I can be contagious...” Exploring the faith of Christian elite athletes using a socio-theological approach." In Gods, Games, and Globalization: New Perspectives on Religion and Sports, edited by A. Remillard \& R. Alpert. Macon, GA: Mercer University Press.

Hoffman, Shirl, J. 2010. Good Game: Christians and the Culture of Sport. Waco, Texas: Baylor University Press.

Horne, John. 2015. "Sports." In Oxford Bibliographies in Sociology, edited by J. Baxter. Oxford: Oxford University Press.

Howe, P. David and Andrew Parker. 2012. "Celebrating imperfection: Sport, disability and celebrity culture." Celebrity Studies 3 (3): 270-282.

Howe, P. David and Andrew Parker. 2014. "Disability as a Path to Spiritual Enlightenment: An ethnographic account of the significance of religion in Paralympic sport." Journal of Disability and Religion 18 (1): 8-23.

Parker, Andrew and Nick, J. Watson. 2014. "Researching Religion, Disability and Sport: Reflections and Possibilities." Journal of Religion, Disability and Health 18 (2): 192-208.

Shilling, Chris and Mellor, Philip, A. 2014. "Re-Conceptualizing Sport as a Sacred Phenomenon." Sociology of Sport Journal 31 (3): 349-376. 
Smith, James, K.A. 2012. "Secular liturgies and the prospects of a 'post-secular' sociology of religion." In The Post Secular in Question. Edited by P. Gorski, D. K. Kim, J. Torpey, and J. VanAntwerpen, 159-184. New York: New York University Press.

Twietmeyer, Gregg. 2008. "A theology of inferiority: is Christianity the source of kinesiology's second-class status in the academy?" Quest 69: 452-466.

Twietmeyer, Gregg. 2009. "Law, gospel, play: Martin Luther and the neglected influence of theology on sport history." Stadion: International Journal of the History of Sport 35: 239255.

Watson, Nick, J. 2011. "Introduction." In Theology, Ethics and Transcendence in Sports. Edited by J. Parry, M.N. Nesti, and N.J. Watson, 1-11. London, UK: Routledge.

Watson, Nick, J. and Andrew Parker. 2013. Sports and Christianity: Mapping the Field. In Sports and Christianity: Historical and Contemporary Perspectives, edited by N.J. Watson and A. Parker, 9-88. New York, Routledge.

Watson, Nick, J. and Andrew Parker. 2014. Sport and the Christian Religion: A Systematic Review of Literature. Newcastle Upon-Tyne: Cambridge Scholars Publishing. 